\title{
The Effect of KAP Size, Management Change, Audit Opinion, and Financial Distress on Auditor Switching in Infrastructure, Utility and Transportation Companies
}

\author{
Firda Farhany Dimyati, Wahyu Ari Andrianto, Retna Sari \\ Fakultas Ekonomi dan Bisnis, University of Pembangunan Nasional Veteran Jakarta, Jakarta, Indonesia \\ Email address: \\ firda.farhany@upnvj.ac.id (F. F. Dimyati),wahyuari@upnvj.ac.id (W. A. Andrianto), retnasari@upnvj.ac.id (R. Sari) \\ To cite this article: \\ Firda Farhany Dimyati, Wahyu Ari Andrianto, Retna Sari. The Effect of KAP Size, Management Change, Audit Opinion, and Financial \\ Distress on Auditor Switching in Infrastructure, Utility and Transportation Companies. Journal of Finance and Accounting. \\ Vol. 8, No. 6, 2020, pp. 257-265. doi: 10.11648/j.jfa.20200806.12
}

Received: September 24, 2020; Accepted: November 9, 2020; Published: November 19, 2020

\begin{abstract}
This study aims to examine the effect of the size of the public accounting firm, change in management, audit opinion, and financial distress on auditor switching at companies listed on the Indonesia Stock Exchange (IDX) selected by using the purposive sampling method. Secondary data used in this study were taken from published annual reports through documentation and literature study methods. Infrastructure, utility, and transportation sector companies are the population in this study. The total number of infrastructure, utility, and transportation sector companies listed on the Indonesia Stock Exchange (IDX) in 2016-2018 in 181 companies. However, the data sample used is as many as 39 companies with an observation time of three years (2016-2017) with a population of 117 companies according to the criteria in this study. Logistic regression analysis is an analytical technique used for this study assisted by Microsoft Excel 2013 and IMB SPSS Statistic 25. The results of the study indicate that the size of the public accounting firm, audit opinion, and financial distress did not have a significant effect on auditor switching. Meanwhile, management changes have a significant effect on auditor switching.
\end{abstract}

Keywords: Auditor Switching, Financial Distress, Audit Opinion, Management Change, and Public Accounting Firm Size

\section{Introduction}

Companies are required to publish their annual reports or financial reports that have been audited by an independent party each year if their shares have been listed on the IDX. This is a form of company management responsibility to interested parties and also to shareholders. The existence of financial reports is intended to provide fair, reliable, and understandable information for users of financial statements, following PSAK No. 1. Because in the financial statements there must be an explanation that can be used in making economic decisions and is also a form of accountability from the manager during the implementation of company management that is entrusted to him. To obtain a financial report that has high credibility, it is necessary to have an examination of the financial report by a certain public accounting firm through an independent auditor which makes the results of the examination of the financial report more convincing for stakeholders. The attitude of independence means that auditors may not take sides or influence certain parties [10].

The engagement between the public accounting firm and the client company occurs because each party has a goal to be achieved. The purpose of the client company in using the services of a public accounting firm is to present an opinion regarding the equity of financial statements as well as to control whether the financial statements comply with applicable standards. Furthermore, the purpose of the Public Accountant is to get a professional income with a certain risk limit that is still acceptable. However, the long-standing engagement between the public accounting firm (examiner) and the client company (assignor) can reduce the audit independence of the public accounting firm so that it can affect the quality of the audit report. Therefore, the engagement that occurs can terminate or can be referred to as Auditor Switching. Auditor switching is an activity that a company does in changing its auditors. To avoid this, rules/regulations governing the obligation to change public 
accounting firms by companies that are regulated in Law No. 5 of 2011 are enacted.

The regulations governing mandatory changes in auditors by PP No. 20 of 2015 regarding the practice of public accountants which explain in detail from Law No. 5 of 2011 concerning public accountants concerning mandatory auditor rotation. Article 11 paragraph 1 of Government Regulation No. 20 of 2011 describes the determination of audit services on historical financial statements of a company by a public accountant which is restricted to a maximum of 5 running financial years. Article 11 paragraph 3 of Government Regulation No. 20 of 2011 describes the determination of audit services on historical financial reports in a company by public accountants who are also associated with the sense of public accountants who are not directly involved/dodo not sign the independent auditor's report.

Furthermore, government regulations that have regulated the replacement of public accounting firms are Minister of Finance Decree No. 423 / KMK.06 / 2002 and Minister of Finance conclusion No. 359 / KMK.06 / 2003 which limit public accounting firms in providing general audit services for financial statements. a maximum of 5 running financial years and limits public accountants to serve general audit services for financial statements for a maximum of 3 consecutive years. Then, this regulation was developed in the Minister of Finance Regulation No. 17 / PMK / 2008 regarding public accounting services. This discusses the restrictions that general audit services for financial statements for companies carried out by public accounting firms for a maximum of 6 running years. According to the background described, this researcher will test the effect of public accounting firm size, management change, audit opinion, and financial distress on auditor switching in infrastructure, utility, and transportation companies.

\subsection{Literature Review}

Agency theory is a contractual relationship as a relationship involving more than 1 person, the principal who is the owner and the agent as the one who carries out certain services in fulfilling the principal's interests [11]. The occurrence of a conflict of interest between the two parties (agent and principal) is due to the always different interests of each party, which results in a conflict of interest. With the conflict of interest that happens, a third party is urgently needed to bridge the interests of each party by inviting an independent auditor. Therefore, we need an independent party, namely an independent auditor who acts as a mediator from the between and the principal.

Auditor Switching (Y)

Auditing is a systematic and critical examination carried out by an independent party on the company's financial statements, which management compiles as well as accounting records and supporting evidence to determine the fairness level of financial statements. In this case, a public accountant provides astesinya services to assess the fairness level of a company's financial statements. As for other asthesia services provided by AP, namely prospective financial reports and reports related to internal control [1]. Auditor switching is an activity of changing an old public accounting firm to a new public accounting firm by a client of a public accounting firm in auditing their company. The implementation of auditor switching aims to defend the independence and quality of the audit so the output of a company's audit report can be trusted in the public eye. The old engagement between the auditor and the client companies loss of the auditor's independence, which results in an economic dependence or bond with the client.

Public accounting firm size (X1)

A public accounting firm is defined as a business entity that can obtain a business license from the minister of finance in acco. Following 5 of 2011 regarding public accounting firms. One of the services provided by a public accounting firm is in the form of general audit services on the financial statements of a company by way of evaluating the financial statements and providing opinions on the financial statements. The size of the public accounting firm reflects the size of the public accounting firm. A public accounting firm is said to be large if it is affiliated with a Big 4 public accounting firm and can be said to be a small public accounting firm if it's not affiliated with a Big 4 public accounting firm [17]. Companies in choosing a public accounting firm for auditing their financial statements must consider things, namely the reputation of the public accounting firm, the quality of auditors, and the professionalism of auditors in the company's business activities. Because, a public accounting firm that has the criteria as above, it can be said that auditing is better and faster in the audit process.

\section{Change Management (X2)}

A company or organization must be led by management. Management is a group of individuals or individuals who have executive responsibility in the company's operating activities [8]. According to Khusna and Dyah (2019), Management change is a change in the board of directors of a company due to the resolution of the GMS or because the board of directors resigns voluntarily. The reason for the change of management is the decision of the GMS or it could be from the management itself who wants to resign/resign from his position. Therefore, this management must be addressed by shareholders so that the company's activities can run in a balanced manner.

Audit Opinion (X3)

The auditor who audits the financial statements will produce an output in the form of an auditor's report regarding his opinion on the company's financial statements. Information from the results of the audit report is provided to interested parties regarding the resume achieved on audited financial reports [3]. According to Alexandros and Dewi (2015), an audit opinion is an opinion or final result of the auditor or public accounting firm after they test the financial statements of their clients. The audit of the financial statements that the independent auditor conducts has the purpose of reporting and also states all matters in the financial statements. Therefore, the provision of an audit opinion must be based on the audit evidence that has been obtained and the audit practice that meets the auditing standards established by the in the audit assignment to produce a reliable audit report. 
Financial Distress (X4)

Financial conditions or what can be referred to as financial distress are conditions that can be explained variously and widely. Faradila and Rizal (2016) explain that financial distress is a financial problem experienced by a company and is worried that it will go bankrupt which has an impact on the survival of the company. The existence of the threat of financial distress is a burden that must be considered by the company because management will waste time avoiding this condition rather than thinking about or discussing ways to find a good solution for the company. The occurrence of increasing financial distress in companies is generally due to increased use of debt so that the interest expense on the company is also high. This shows the higher the probability of a decrease in income resulting in financial distress [19].

\subsection{Hypothesis Development}

\subsubsection{The Effect of Public Accounting Firm Size on Auditor Switching}

The size of a public accounting firm becomes a determinant of the size or size of a public accounting firm. Public accounting firms affiliated by the Big 4 can be said to be large public accounting firms and public accounting firms that are not affiliated by the Big 4 can be said to be small public accounting firms [17]. In agency theory, corporate agents must try to obtain audit services from a public accounting firm that has a good audit reputation in assessing financial statements so that the principal does not experience information asymmetry. Julianti \& Rasmini's research (2013) explains that the big four public accounting firm is a public accounting firm that has a good reputation in the world because, from that good reputation, widespread connections can be created. With this, it will attract investors, and of course, investors are more confident about the companies audited by the Big 4 public accounting firm because they consider the results audit quality to be more credible than the non-big 4 public accounting firms. Parallel with Alexandros and Dewi (2015), Irma et al., (2019), dhanar and Indah (2017) stated that the size of the public accounting firm influences auditor switching. Following the arguments that have been described, the following hypotheses are formulated:

$\mathrm{H}_{1}$ : The size of the public accounting firm affects auditor switching.

\subsubsection{The Effect of Management Change on Auditor Switching}

Management changes that occur in a company allow for changes to its financial accounting policies. In connection with agency theory, where each party (agent and principal) has the objective of maximizing its interests, but the agent does not maximally uphold the interests of the principal which causes a conflict of interest. This can trigger the principal to decide to change management in the company. This change in management makes it possible to make changes to accounting policies which are followed by changes in the public accounting firm/auditor. The research of Khalimatus and Andi
(2018) states that if a company makes changes to the board of directors (directors or commissioners) it will cause a change in policy in the company. This is parallel with Alexandros and Dewi (2015), Irma et al., (2019), and Alazhar (2015) which state that changes in management affect auditor switching. From the arguments outlined above, the following hypothesis is formulated:

\section{$\mathrm{H}_{2}$ : Management changes affect Auditor switching}

\subsubsection{The Effect of Audit Opinion on Auditor Switching}

Audit opinion aims to convey information to users of financial statements and is useful for investors' consideration in investing. In agency theory, principals need financial reports to find out information about the state of the company, as well as investors. Investors will certainly prefer to invest in companies whose financial and non-financial performance has proven fairness. Siti and Dhini (2019) explain the audit opinion on financial reports that bridges the company in building a good image in the eyes of the public so that external parties can measure the management performance of a company. Companies that receive an opinion can encourage the company's image and good relations with investors. This is espoused by the research of Irma et al., (2019), Novi (2017), and AlAzhar (2015) which states that audit opinion affects switching auditors. Following the arguments outlined above, the following hypotheses are formulated:

$\mathrm{H}_{3}$ : Audit opinion influence auditor switching

\subsubsection{The Effect of Financial Distress on Auditor Switching}

An entity with a condition that is threatened with bankruptcy is possible in auditor switching. This is because, under a condition that is threatened with bankruptcy, it encourages companies to increase their prudence and subjectivity in selecting audiences so that companies tend to do audience switching. Financial difficulties that occur in the company can affect the change of auditors [7]. This is espoused by the research of Alexandros and Dewi (2015) and Alazhar (2015). If the company is not in a financial condition, the company will not make a replacement. auditors and maintain the public accounting firm or its auditors. If the company experiences financial difficulties, it is possible for the auditor switching to occur to reduce the cost of auditing services charged by the public accounting firm.:

\section{$\mathrm{H}_{4}$ : Financial Distress influences the Auditor Switching}

\section{Research Methodology}

The population in this study uses objects from companies in the infrastructure, utility, and transportation sectors listed on the IDX for the period 2016-2018. The data obtained are got from the official IDX website www.idx.co.id as well as the official website of the related entities which can be accessed directly. Overall data from this research were analyzed and tested by logistic regression analysis models. Purposive sampling is used to determining this sample with certain criteria: 
Table 1. Determination of Samples according to the criteria.

\begin{tabular}{lll}
\hline No. & Research Sample Criteria & Jumlah \\
\hline 11. & Companies in the utility and transportation infrastructure sectors that have been listed on the IDX in 2016-2018 & 181 \\
12. & Companies that do not report financial data are complete and new listings and delisting companies on the IDX in 2016-2018 & $(39)$ \\
& The total number of companies that were sampled & 39 \\
& Number of observation periods & 3 \\
& Total sample in the observation period & 117 \\
\hline
\end{tabular}

Source: Indonesia Stock Exchange website (www.idx.co.id) \& related company website (processed).

\section{Research Variable}

\subsection{The size of the Public Accounting Firm}

The size of the public accounting firm is reflected in the size of the public accounting firm. A public accounting firm is categorized as large if affiliated with a Big 4 public accounting firm and categorized as a small public accounting firm if it is not affiliated with a Big 4 public accounting [17]. Measurements in this variable use a dummy variable, companies with Big 4 public accounting firm audit services get a score of 1 (one), and companies with big 4nonpublicc accounting firm audit services get a score of 0 (zero) [4].

\subsection{Management Change}

The management change is defined as the change in the board of directors of a company cause of the decision of the General Meeting of Shareholders or the board of directors resigned voluntarily [15]. Measurements in this variable use dummy variables, where companies that make changes or changes in directors will be given a score of 1 , and companies that do not make changes or change the chairman of the board of directors will be given a score of 0 [14].

\subsection{Audit Opinion}

Audit opinion, namely the opinion or final result of the auditor or public accounting firm after check the financial statements of the client's company. Measurements in this variable with a dummy variable, a score of 1 if the client company gets an unqualified opinioni, $\mathrm{n}$ and a score of 0 if the client company gets an opinion other than unqualified [2].

\subsection{Financial Distress}

Financial distress, namely financial difficulties experienced by a company and worrying about bankruptcy which has an impact on the survival of the company [7]. Measurements in this variable using the Altman Z-Score formula (non-manufacturing companies): $Z=6.56 \mathrm{~T} 1+3.26 \mathrm{~T} 2+6.72 \mathrm{~T} 3+1.05 \mathrm{~T} 4$ with the following information $=\mathrm{T} 1$ : Working Capital $(\mathrm{WC}) /$ Total Assets (TA), T2: Retained Earnings (EA) / Total Assets (TA) T3: Earnings before interest and taxes (EBIT) / Total assets (TA), T4: Market value of equity. As for the classification: if Z> $2,6=$ the company's financial condition is considered safe, if 1.1 $<\mathrm{Z}<2,6=$ the company's financial condition needs to be carefl, if $Z<1.1=$ the company will have the potential to go bankrupt.

\section{Results and Discussion}

\subsection{Descriptive Statistical Analysis}

Table 2. Results of Descriptive Statistical Analysis Analysis.

\begin{tabular}{llllll}
\hline Descriptive Statistics & & & & \\
\hline & N & Min. & Max. & Mean & Std. Deviation \\
\hline FD & 117 & -275.2595 & 15.8203 & -1.47879 & 26.4278 \\
Valid N (listwise) & 117 & & & & \\
\hline
\end{tabular}

Source: 2020 data processed.

From the results above, the variable financial distress (FD) with a total of 117 company samples shows that the minimum value of -275.25 that the company in financial difficulty. The maximum value of 15,820 that the company is not infinanciall difficulty. The mean value shows -1.47 and the standard deviation value of this analysis is 26,427 , which means it is greater than the value (mean), namely -1.47 , so it can be concluded that the financial distress (FD) data in this study have low distribution and fluctuation.

Table 3. Auditor Switching Frequency.

\begin{tabular}{|c|c|c|c|c|c|}
\hline & & Frequency & Percent & Valid Percent & Cumulative Percent \\
\hline \multirow{3}{*}{ Valid } & 0 & 79 & 66.9 & 68.1 & 68.1 \\
\hline & 1 & 37 & 31.4 & 31.9 & 100.0 \\
\hline & Total & 116 & 98.3 & 100.0 & \\
\hline Total & & 118 & 100.0 & & \\
\hline
\end{tabular}

Source: 2020 data processed. 
It is known that the sample of companies that did not change auditors was $66.9 \%$ with 79 companies and the sample of companies that did change auditors was $31.9 \%$ as many as 37 companies. Thus, many of the sample firms in this study did not perform auditor changes than did auditors.

Table 4. Frequency of Public Accounting Firm Size.

\begin{tabular}{|c|c|c|c|c|c|}
\hline & & Frequency & Percent & Valid Percent & Cumulative Percent \\
\hline \multirow{3}{*}{ Valid } & 0 & 76 & 64.4 & 65.0 & 65.0 \\
\hline & 1 & 41 & 34.7 & 35.0 & 100.0 \\
\hline & Total & 117 & 99.2 & 100.0 & \\
\hline Missing & System & 1 & .8 & & \\
\hline Total & & 118 & 100.0 & & \\
\hline
\end{tabular}

Source: 2020 data processed.

It is known that the sample of companies that do not use the Big 4 public accounting firm is $64.4 \%$ with 76 companies and the sample of companies that use of Big 4 public accounting firm is $34.7 \%$ with 41 companies. So, the sample of companies in this study are mis who do not use the services of a Big 4 public accounting firm than those that use the services of a Big 4 public accounting firm.

Table 5. Frequency of Management Change.

\begin{tabular}{llllll}
\hline & & Frequency & Percent & Valid Percent & Cumulative Percent \\
\hline \multirow{3}{*}{ Valid } & 0 & 100 & 84.7 & 85.5 & 85.5 \\
& 1 & 17 & 14.4 & 14.5 & 100.0 \\
Missing & Total & 117 & 99.2 & 100.0 & \\
Total & System & 1 & .8 & & \\
\hline
\end{tabular}

Source: 2020 data processed.

It is known that the sample of companies that did not change management was marked by no change or change from the chief of the board of directors of $84.7 \%$ with a total of 100 companies, while the sample companies in this study that made changes in management were marked by a change or change in the chairman of the board of directors by $14.4 \%$ with a total of 17 company. Thus, the sample of companies in this study dominantly did not make management changes compared to those that made management changes.

Table 6. Audit Opinion Frequency.

\begin{tabular}{|c|c|c|c|c|c|}
\hline & & Frequency & Percent & Valid Percent & Cumulative Percent \\
\hline \multirow{3}{*}{ Valid } & 0 & 65 & 55.1 & 55.6 & 55.6 \\
\hline & 1 & 52 & 44.1 & 44.4 & 100.0 \\
\hline & Total & 117 & 99.2 & 100.0 & \\
\hline Missing & System & 1 & .8 & & \\
\hline Total & & 118 & 100.0 & & \\
\hline
\end{tabular}

Source: 2020 data processed.

It is known that the sample of research companies did not get an unqualified opinion of $55.1 \%$ with 65 companies and $44.1 \%$ with 52 companies had an unqualified opinion. Thus, most of the sample did not receive an unqualified opinion compared to those who received an unqualified opinion.

\subsection{Hypothesis Testing and Analysis}

\subsubsection{Model Feasibility Test Analysis}

Table 7. Model Feasibility Test.

\begin{tabular}{|c|c|c|c|}
\hline \multicolumn{4}{|c|}{ Hosmer and Lemeshow Test } \\
\hline Step & Chi-square & df & Sig. \\
\hline 1 & 7.003 & 8 & .536 \\
\hline
\end{tabular}

Source: 2020 data processed.

It is known the value is worth 7,003 and a signcant value of
0.536 which $0.536>0.05$ so the model can be said to be capable to predict the observation data / it is in accordance with the observation data also the model is said to be good or fit.

\subsubsection{Overall Model Test Analysis}

Table 8. Test the Whole Model.

\begin{tabular}{ll}
\hline & Chi-square \\
\hline-2 Log Likelihood awal (Block Number $=0)$ & 145.252 \\
-2 Log Likelihood akhir (Block Number $=1)$ & 130.574 \\
\hline
\end{tabular}

Source: 2020 data processed.

It is known from the table above that there is a reductiom in the -2 Log Likelihood value of 14,678. In conclusion, the addition of independent variables in the model can adjust the overall model fit and can also indicated a good regression model. 
Table 9. Omnibus Tests of Model Coefficients.

\begin{tabular}{lllll}
\hline & & Chi-square & df & Sig. \\
\hline \multirow{2}{*}{ Step 1 } & Step & 14.678 & 4 & .005 \\
& Block & 14.678 & 4 & .005 \\
.005 & 4 \\
\hline
\end{tabular}

Source: 2020 data processed.

It is known that the significance level of the difference between the initial $2 \mathrm{~L}$ and the final -211 value is 0.05 . The above analysis shows that the calculated chi-square $>$ chi-square value $(14,678>9,48733)$. So it can be concluded that the addition of the variable size of the public accounting firm, change in management, audit opinion, financial distress can improve the overall model so that the model is worthy of interpretation in this study.

\subsubsection{Analysis of the Coefficient of Determination Test (Nagelker's R Square)}

Table 10. Determination Coefficient Test.

\begin{tabular}{llll}
\hline Model Summary & & Cox \& Snell R Square & Nagelkerke R Square \\
\hline Step & $\mathbf{- 2}$ Log likelihood & .119 & .166 \\
\hline 1 & $130.574^{\text {a }}$ & \\
\hline
\end{tabular}

Source: 2020 data processed.

It is known that table is worth 0.166 , which that the dependent variable in this study can be defined with independent variables valued at $16.6 \%$ and the remaining $83.4 \%$ which is explained from each variable not included in this study.

\subsubsection{Classification Table}

Table 11. Classification Table.

\begin{tabular}{|c|c|c|c|c|c|}
\hline & \multirow{3}{*}{\multicolumn{2}{|c|}{ Observed }} & \multicolumn{3}{|c|}{ Predicted } \\
\hline & & & \multicolumn{2}{|l|}{ AS } & \multirow{2}{*}{ Percentage Correct } \\
\hline & & & NON AS & AS & \\
\hline \multirow{3}{*}{ Step 1} & \multirow{2}{*}{ AS } & NON AS & 74 & 5 & 93.7 \\
\hline & & AS & 30 & 7 & 18.9 \\
\hline & \multicolumn{2}{|c|}{ Overall Percentage } & & & 69.8 \\
\hline
\end{tabular}

Source: 2020 data processed.

It is known, regarding the predictive ability of the regression model in order to estimate the overall auditor turnover as much as $69.8 \%$ of the sample which can be predicted well in this logistic regression model. It is predicted that as many as 79 sample companies did not change auditors, only 5 sample companies had auditor changes, which means the forecast power of regression model in order to predict that those who did not change auditors was likely as much as $93.7 \%$.

Furthermore, it is predicted that as many as 37 sample companies made auditor changes, only 7 sample companies made auditor changes and the rest did not change auditors, which means that the prediction power of the regression model to predict that implementing auditor changes correctly is likely to be $69.8 \%$.

\subsubsection{Multicollinearity Test}

Table 12. Multicollinearity Test.

\begin{tabular}{|c|c|c|c|c|c|c|}
\hline \multicolumn{7}{|c|}{ Correlation Matrix } \\
\hline & & Constant & UKAP & PM & $\mathbf{O A}$ & FD \\
\hline \multirow{5}{*}{ Step 1} & Constant & 1.000 & -.186 & -.316 & -.451 & .047 \\
\hline & UKAP & -.186 & 1.000 & -.204 & -.559 & -.026 \\
\hline & $\mathrm{PM}$ & -.316 & -.204 & 1.000 & .188 & -.005 \\
\hline & OA & -.451 & -.559 & .188 & 1.000 & -.081 \\
\hline & FD & .047 & -.026 & -.005 & -.081 & 1.000 \\
\hline
\end{tabular}

Source: 2020 data processed.

It is known, the correlation value/relationship between variables is not more than 0.9 . So the conclusion is that there is no correlation between the independent variables in this study or the absence of multicollinearity. 


\subsubsection{The Formed Logistic Regression Model and Hypothesis Test}

Table 13. Hypothesis testing.

\begin{tabular}{|c|c|c|c|c|c|c|c|}
\hline \multicolumn{8}{|c|}{ Variables in the Equation } \\
\hline & & B & S.E. & Wald & df & Sig. & Exp (B) \\
\hline \multirow{5}{*}{ Step $1^{\mathrm{a}}$} & UKAP & .951 & .526 & 3.269 & 1 & .071 & 2.587 \\
\hline & PM & 1.171 & .573 & 4.169 & 1 & .041 & 3.225 \\
\hline & OA & .098 & .520 & .035 & 1 & .851 & 1.103 \\
\hline & FD & -.026 & .027 & .970 & 1 & .325 & .974 \\
\hline & Constant & -1.384 & .327 & 17.891 & 1 & .000 & .251 \\
\hline
\end{tabular}

Source: 2020 data processed.

Based on table 13 above, the following is a regression model that is formed:

$$
\text { SWITCT }_{t}=-1.384+0.951 \text { UKAP }+1.171 P M+0.098 A-0.026 F D+\epsilon
$$

Testing the logistic irregularity in which the constant value (a) and the coefficient value of each independent variable data are interpreted into four parts. First, explained the influence of company size (UKAP) on auditory switching. Second, to explain the effect of management change (PM) on auditory switching. Third, explaining the effect of audited opinion (OA) switching auditors. Fourth, explains the financial distress (FD) to auditor switching.

\section{Discussion}

This study was conducted to find out the effect of the size of the KAP, changes in management, audited opinions, and financial distress on auditory switching. The results of the determination coefficient test are following the Nagelkerke'si Square table which shows the independent variables in this research, the size of KAP, change in management, audit opinion, financial distress are not sufficient to influence the dependent variable of this research because auditor switching only has an effect of $28 \%(0.280)$ and the rest. amounting to $72 \%$ which is influenced by other variables outside of this research.

From the results of testing the hypotheses developed in this study, the following conclusions can be drawn:

Table 14. Results of Hypothesis Testing Analysis.

\begin{tabular}{lll}
\hline & Hypothesis & Result \\
\hline H1 & The size of the Public Accounting Firm does not have a significant effect on Auditor Switching & rejected \\
H2 & Management changes affect Auditor Switching & accepted \\
H3 & Audit Opinion affects Auditor Switching & rejected \\
H4 & Financial Distress has no efdoes not affectSwitching & rejected \\
\hline
\end{tabular}

Source: 2020 data processed.

\subsection{The Effect of Public Accounting Firm Size on Auditor Switching}

In the test above, the variable size of the public accounting firm doesn't have a significant effect on auditor switching, which in this research the results are not following the first hypothesis (h1) that the public accounting firm size affects auditor switching. This informs that the size of the public accounting firm is not a determinant of the entity in conducting auditor switching, but the entity will certainly see the quality of a public accounting firm in order to the quality of financial statements. The non-Big 4 public accounting firm will also try to deliver better audit quality according to the applicable professional auditing standards so that this variable does not determine the company in carrying out auditor switching on the grounds thabecauser audit quality results than the Big 4 public accounting firm. If the company performs auditor switching, the start-up costs for auditors will also increase, because the new auditors do not fully understand the company's environment as well as the audit risks of their clients. This result is support by research of Kristini and Nahumury (2014) and Alisa et al., (2019) which stated that the entities audited by the Big 4 public accounting firm tend to maintain that it is also less likely to do auditor switching $[12,2]$. There is another factor in the form of expertise factor which can determine changes in the company in maintaining / running the Big 4 public accounting firm which aims to increase the capability of the company in the eyes of the public or capital market players. The results of the researcch is not supported by previous research, namely Wea and Murdiawati and Damayanti et al. which state that the Big 4 public accounting firm is a public accounting firm that has advantages in the international arena because the Big 4 public accounting firm has extensive connections too have experienced and competent auditors [18, 5]. Therefore, investors and companies will be more confident that they use the services of the Big 4 public accounting firm and are considered to be able to make good audit reports.

\subsection{The Effect of Management Changes on Auditor Switching}

In the test above, the variable management change affects auditor switching, which in this study the results are in accordance with hypothesis two (h2) which puts public accountants on changes in management influence on auditor 
switching. This shows that companies that make management replacement are often followed by replacement in company policy, so that the entity implements auditor switching. If an entity makes changes to the board of directors it can result in replacement company policy. In this case, management hopes that the new public accounting firm can be invited to cooperate and produce the opinion that the management hopes for. So if a company makes a management change, it will indirectly encourage auditor switching because an entity will definitely seek out a public accounting firm that can be invited to work with it can also adjust company policies or be aligned in the reporting and accounting policies of the company so as to produce the opinion expected by management.. The results of this study are supported by Sa'adah \& Kartika and Alisa et al. which state that management changes are due to decisions at the time of the rups $[16,2]$. With the change in management in the company, it encourages auditor switching so that the company gets the right auditor and agrees with existing accounting policies. The outcome of this research is not supported by research by Damayanti et., Al, that many entities that make management changes but are not followed by policy changes, so there is no need to change auditors and change policies because they think that policies are not problematic and can be implemented [9].

\subsection{The Effect of Audit Opinion on Auditor Switching}

From the above test, the audit opinion variable does not affect auditor switching, wherein this study the results do not accept the triple hypothesis (h3) which places a public accountant on the audit opinion that does not affect auditor switching. This shows that 52 samples of companies in this study received unqualified opinion so that the company is satisfied with the opinion obtained, making the company not doing so, also companies that have used the services of big4 / non-big4 public accounting firms may not run auditor switching if they have obtained a fair opinion without exception. Companies that get a fair opinion without exception from the auditor, the company tries to retain the auditor because it is satisfied with the opinion obtained. The management will of course also retain an auditor who can give an opinion in agreement with the company to maximize the interests of the shareholders which are the responsibility of management to the shareholders. The outcome of this research support researchers from Sa'adah \& Kartika who explain that companies with Big 4 and non-Big 4 public accounting firms if they have obtained an unqualified opinion do not change auditors [16]. The results of the study are not supported by research Darmayanti and Alazhar which explain that getting an opinion other than an unqualified opinion will be moved to change auditors to get the opinion that the company wants $[6,13]$.

\subsection{The Effect of Financial Distress on Auditor Switching}

From the test above, the financial distress variable has no effect on auditor switching, where the results are not following hypothesis four (h4) which states that public accountants do not affect thditor switching. This shows that companies that are in financial difficulty do not change auditors because they are defindering an audit fee if they want to change auditors as well as companies that increase their evaluation of subjectivity and are more careful in choosing a new auditor. If the company changes auditors and gets a higher audit fee than the previous auditor, it will worsen the company's financial condition. Changing auditors (auditor switching) which is too frequent arell increase the start-up costs of auditors. The outcome of this research is supported by Damayanti et al., (2019) which explains that the company's condition in financial distress doesn't always do auditor switching, cause new auditors are defking for information related to the company financially and nonfinancially so that opinions will be obtained from the company's condition that time [5]. financial distress will be the same. This is not supposed the research of Wea and Murdiawati, Alazhar describes that financial disaffects on auditors switching because it is statistically a driving force for auditor switching companies [18, 13]. This can happen because the company wants to find a public accounting firm auditor that can provide services but at a cost that is appropriate and affordable to the condition of the company that is experiencing financial distress.

\section{Conclusion}

This research aims to see the effect of public accounting firm size, management change, audit opinion, and financial distress on auditor switching. In the Following results of the analysis that has been conducted, the conclusion can be given that the size of the public accounting firm does not have a significant effect on auditing switching. This shows that the size of the public accounting firm is not a determinant for the company to carry out auditory switching, but the company must see the quality of a public accounting firm in order to the quality of financial reports and also if the company performs auditor switching, the start-up costs for auditors also increase because auditors just do not understand the business environment of the corporation/clients and the audit risks of the client.

Meanwhile, the change in management affects auditor switching. This shows that many of the companies that make management replacements are often followed by changes to corporation policies so that the companies do auditor switching. If a corporation makes changes to the board of directors or commissioners, will be a replacement in ideals in the company's policies. So if a company makes a change in management, it indirectly encourages auditors to switch because a company certainly tends to look for a public accounting firm that can be invited to work with and can adjust company policies or be aligned in the reporting and accounting policies of the company to generate the opinion expected by management. For the audit opinion variable it does not affect the auditory switching. This shows that the sample of this research company generally has received a 
teaching opinion without exception so that they are satisfied with the acceptance of this opinion which makes companies not need to do auditor switching and also companies that use public accounting firm services Big 4 and Non big 4 tend not to do auditors. switching if it has received a fair opinion without any exceptions.

Another variable studied, namely financial stress has no significant effect on auditor switching. This shows that companies that are experiencing financial distress do not always conduct audit switching because companies experiencing financial difficulties consider auditing if they want to do auditory switching and also companies that increase the evaluation of subjectivity and are more careful in selecting new auditors. If the company performs auditory changes and gets a higher auditing rate than the previous auditor, it will worsen the company's financial condition. Changes in auditors (auditor switching) that have been carried out often increase the cost of auditory startups, namely the understanding of the business environment and the risks to client audits.

The limited number of samples is due to some companies providing incomplete data related to this research, the research period which was only carried out for 3 (three) years (2016 - 2018), and research which is only in the scope of infrastructure, utility and transportation companies. Limit the study of this. So that further research is expected to be found. do research. In some company sectors, it is possible to add several variables related to auditor switching such as audit delay, audit fee, audit tenure, or client company size, and extend the observation year.

\section{References}

[1] Agoes, S. (2017). Auditing. Jakarta: Salemba Empat.

[2] Alisa, A. I., Intan, A. R. D., dan Fradini, B. (2019). “The Effect of Audit Opinion, Change of Management, Financial Distress, and Size of A Public Accounting Firm On Auditor switching”. Jurnal Akuntansi Trisakti, 6 (1), 55-68. ISSN: 2339-0832.

[3] Arens dan Loebbecke J. K. (2003). "Auditing; Pendekatan Terpadu Buku 1 dan 2 Edisi Ketiga”. Jakarta: Salemba Empat.

[4] Arsih, L., dan Anisyukrillah, I. (2015). "Pengaruh Opini Going Concern, Ukuran Kantor Akuntan Publik, dan Profitabilitas terhadap Auditor Switching”. Accounting Analysis Journal. Vol. 4, No. 3.

[5] Damayanti., Widaryanti., Wahyuningsih, P. (2019). "Analisis Faktor-Faktor yang Mempengaruhi Auditor switching di Indonesia". Prosiding Mahasiswa Seminar Nasional Unimus, Vol. 2. ISSN: 2654-766X.

[6] Darmayanti, N. (2017). "The effect of audit opinion, financial distress, client size, management turn over and kantor akuntan publik size on Auditor switching". Journal of Economics, Business, and Accountancy Ventura, 20 (2), hlm. 237-248.

[7] Faradila, Y., dan M. Rizal, Y. (2016). "Pengaruh Opini Audit, Financial Distress, dan Pertumbuhan Perusahaan Klien terhadap Auditor Switching” (Studi Perusahaan Manufaktur yang Terdaftar di Bursa Efek Indonesia tahun 2010-2014)”. Jurnal Ilmiah Mahasiswa Ekonomi Akuntansi (JIMEKA), Vol. 1 No. 1, hlm. 81-100.

[8] Harvianto, Bayu P. (2015). "Faktor-Faktor yang Mempengaruhi Pergantian Kantor Akuntan Publik (Auditor Switchig)". Jurnal Faculty of Economic Riau University.

[9] Hidayati, K., dan Dyah, E. S. J. (2019). Auditor Switching: "Faktor-Faktor yang Mempengaruhi (Studi Empiris pada perusahaan Real Estate dan Properti di Indonesia)". Jurnal Ekonomi STIE H Agus Salim Bukittinggi, Vol. 22 No. 1. EISSN: 2684-9127.

[10] Ikatan Akuntan Indonesia. (2013)."'Standar Profesional Akuntan Publik". Jakarta: Salemba.

[11] Jensen, Michael C., dan Meckling, William H. (1976). "Theory of The Firm: Managerial Behavior, Agency Costs and Ownership Structure”. Journal of Financial Economics, Vol. 3 No. 4, hlm. 305-360.

[12] Kristini, D. S., dan Nahumury, J. (2014). "The effect of public accounting firm size, financial distress, institutional ownership, and management change on the Auditor switching in manufacturing companies listed in Indonesia Stock Exchange". The Indonesian Accounting Review, 4 (2), hlm. 185-194.

[13] L, AlAzhar. (2015). "Influence of Financial Distress, Management Turnover and Audit Opinion to Auditor switching (Empirical Study on Manufacturing Companies Listed on The BEI During 2011-2013 Period"). Research Journal of Finance and Accounting, 6 (24). ISSN 2222-1697 (Paper) ISSN 2222-2847 (Online).

[14] Permatasari, R., \& Hotman, T. (2016). "Analisis FaktorFaktor yang Berpengaruh Terhadap Auditor switching". Jurnal Informasi, Perpajakan, Akuntansi dan Keuangan Publik vol. 11 No. 1.

[15] Rahmawati, D., Deannes, I., dan Siska, P. Y. (2017). "Pengaruh Pergantian Manajemen, Opini Audit, Pertumbuhan Perusahaan, dan Financial Distress Terhadap Auditor switching (Studi pada Perusahaan Manufaktur yang Terdaftar di Bursa Efek Indonesia Tahun 2010-2015)". e-Proceeding of Management, 4 (2), 1715. ISSN: 2355-9357.

[16] Sa'adah, K., dan Kartika, A. (2018). "Faktor-Faktor yang Mempengaruhi Perusahaan Melakukan Auditor switching (Studi Empiris pada Perusahaan Manufaktur di BEI Tahun 2015-2016"). Dinamika Akuntansi, Keuangan dan Perbankan, 7 (2), 132-146. ISSN: 2656-4955 (media online): 2656-8500 (media cetak).

[17] Sholihat, Walmi, R., Adri S. S., dan Pipin Kurnia. (2014). "Analisis Faktor yang Mempengaruhi Perpindahan kantor akuntan publik di Indonesia (Studi Empiris pada Perusahaan Manufaktur yang Terdaftar di BEI Tahun 2010-2012)”. JOM FEKOM, 1 (2).

[18] Wea, A. N. S. dan Murdiawati, D. (2015). "Faktor-Faktor yang Mempengaruhi Perusahaan Auditor switching pada Perusahaan Manufaktur". Jurnal Bisnis dan Ekonomi (JBE), 22 (2), hlm. 154-170. ISSN: 1412-3126.

[19] Williams, D. D. (1998). "The Potential Determinants of Auditor Change". Journal of Business Finance and Accounting, 15 (2), hlm. 61-243. 